\title{
ANALISIS FAKTOR-FAKTOR YANG MEMPENGARUHI PENYERAPAN TENAGA KERJA DI KOTA JAMBI
}

\author{
DEVITA ANDRI ${ }^{1}$, IRMANELLY ${ }^{2}$ \\ andridevita86@yahoo.com ${ }^{1}$, 73irmanelly@gmail.com²
}

\section{Program Studi Ekonomi Pembangunan Universitas Muhammadiyah Jambi}

\begin{abstract}
ABSTRAK
Tujuan dari penelitian ini untuk mengetahui dan menganalisis penyerapan tenaga kerja di Kota Jambi. Kedua, menganalisis pengaruh faktor-faktor yang mempengaruhi penyerapan tenaga kerja di Kota Jambi. Metode penelitian yang digunakan adalah analisis data sekunder dengan tujuan penelitian ini adalah metode analisis deskriptif untuk menjawab tujuan pertama yang digunakan untuk mengetahui seberapa besar peningkatan angkatan kerja di Kota Jambi dari waktu ke waktu dalam rangkaian data selama kurun waktu 2007 sampai dengan 2018. Hasil analisis yang dilakukan menyimpulkan, pertama, perkembangan penyerapan tenaga kerja di Kota Jambi juga mengalami peningkatan yang fluktuatif selama periode 2007-2018. Kedua, secara parsial berdasarkan uji $\mathrm{t}$ dan uji $\mathrm{F}$ variabel bebas pertumbuhan ekonomi (X1), investasi (X2) dan upah minimum provinsi (X3) berpengaruh positif dan signifikan terhadap penyerapan tenaga kerja (Y) di Kota Jambi selama periode 2007-2018.
\end{abstract}

Kata Kunci: Pertumbuhan Ekonomi, Investasi, Upah Minimum Provinsi dan Penyerapan Tenaga Kerja

\section{ABSTRACT}

This study is entitled "Analysis of Factors Affecting Labor in the City of Jambi". The purpose of this study is the first to determine and analyze the absorption of labor in Jambi City. Second, to analyze the influence of the factors that influence the absorption of labor in Jambi City. The research method used is secondary data analysis with the aim of the research is descriptive analysis method to answer the first objective used to identify how much increase in the workforce in Jambi City from time to time in a series of data during the period 2007 to 2018. Both tools The analysis used is multiple linear regression using the SPSS series 22 application. The results of the analysis carried out concluded, firstly, the development of labor absorption in Jambi City also experienced fluctuating increases during the 2007-2018 period. Second, partially based on the $t$ test and $F$ test of the independent variable of economic growth $\left(X_{1}\right)$, investment $\left(X_{2}\right)$ and the provincial minimum wage $\left(X_{3}\right)$ have a positive and significant effect on labor absorption (Y) in Jambi City during the 20072018 period.

Keywords: Economic Growth, Investment, Provincial Minimum Wages and Labor Absorption 


\section{PENDAHULUAN}

\section{Latar Belakang}

Secara makro pertumbuhan atau kenaikan PDRB dari tahun ke tahun merupakan salah satu indikator dari keberhasilan pembangunan daerah, dimana dalam hal ini PDRB disumbangkan oleh berbagai sektor ekonomi. Indikator penting yang dapat dilihat dari pembangunan ekonomi daerah, terutama untuk meningkatkan dan memberdayakan potensi yang dimiliki oleh daerah dalam rangka memberdayakan ekonomi masyarakat adalah dengan memperhatikan struktur perekonomiannya melalui kajian terhadap Produk Domestik Regional Bruto (PDRB). Namun didalam perekonomian tidak selalu mengalami kenaikan PDRB riil, adakalanya PDRB riil suatu perekonomian mengalami perlambatan dalam pertumbuhan atau bahkan menurun berada pada tingkat yang lebih rendah dari periode sebelumnya, atau dengan kata lain perekonomian tidak selalu berkembang secara teratur, ia selalu naik dan turun.

Pembangunan ekonomi daerah pada dasarnya bertujuan untuk meningkatkan taraf hidup dan mendorong pemerataan. Serta memperluas kesempatan kerja dan kesempatan berusaha, sehingga diharapkan dapat mempertinggi kesejahteraan masyarakat. Upaya menciptakan pemerataan pembangunan melalui peningkatan kesempatan kerja dan berusaha yang lebih besar pada masyarakat di seluruh wilayah, dengan demikian apabila peluang berusaha dan bekerja tersebut menyebar diseluruh wilayah akan mendorong pemerataan peluang usaha dan kegiatan pembangunan, sehingga pembangunan tidak hanya terpusat pada satu wilayah saja tetapi lebih menyebar ke wilayah lain yang berimplikasi pada perubahan tingkat sosial ekonomi masyarakat hingga kedaerah-daerah.

Berdasarkan data dari BPS Kota Jambi tercatat jumlah tenaga kerja Kota Jambi yang bekerja tahun 2010 sebanyak 218.401 jiwa dan terakhir di tahun 2018 masyarakat yang bekerja di Kota Jambi menjadi 277.802 jiwa. Untuk tingkat partisipasi angkatan kerja (TPAK) Kota Jambi tahun 2010 sebesar 57,54 persen dan terus meningkat hingga di tahun 2018 TPAK Kota Jambi sebesar 65,79 persen.

Sedangkan jumlah pengangguran di Kota Jambi di tahun 2010 sebanyak 18.535 jiwa dan di tahun 2018 menjadi 19.488 jiwa. Tingginya jumlah pengangguran di Kota Jambi di tahun 2018 dikarenakan pertumbuhan ekonomi Kota Jambi yang sedikit melambat di tahun 2018 dengan pertumbuhan ekonominya sebesar 5,48 persen. Sedangkan 2010 pertumbuhan ekonomi Kota Jambi tumbuh sebesar 6,66 persen. 
Sehubungan dengan hal diatas, maka permasalahan yang akan diteliti dan dibahas adalah sebagai berikut:

1. Bagaimana perkembangan penyerapan Tenaga Kerja di Kota Jambi?.

2. Faktor-faktor apa saja yang mempengaruhi penyerapan Tenaga Kerja di Kota Jambi?

\section{TINJAUAN PUSTAKA}

\section{Penyerapan Tenaga Kerja}

Penyerapan tenaga kerja adalah diterimanya para pelaku tenaga kerja untuk melakukan tugas sebagaimana mestinya atau suatu keadaan yang menggambarkan tersedianya pekerjaan atau lapangan pekerjaan untuk diisi oleh pencari kerja (Todaro, 2003). Penyerapan tenaga kerja secara umum menunjukkan besarnya kemampuan suatu perusahaan dalam menyerap tenaga kerja untuk menghasilkan suatu produk. Kemampuan untuk menyerap tenaga kerja besarnya tidak sama antara sektor satu dengan sektor lainnya.

Sektor yang mempekerjakan banyak orang umumnya menghasilkan barang dan jasa yang relatif besar. Setiap sektor mengalami laju pertumbuhan yang berbeda. Demikian pula dengan kemampuan setiap sektor dalam menyerap tenaga kerja. Perbedaan laju pertumbuhan tersebut mengakibatkan dua hal. Pertama, terdapat perbedaan laju peningkatan produktivitas kerja di masing-masing sektor. Kedua, secara berangsur angsur terjadi perubahan sektoral, baik dalam penyerapan tenaga kerja maupun dalam kontribusinya dalam pendapatan nasional (Simanjuntak, 2001).

Penyerapan tenaga kerja juga dapat diartikan banyaknya lapangan kerja yang sudah terisi yang tercermin dari banyaknya jumlah angkatan kerja yang bekerja.Penduduk tersebut terserap dan tersebar di berbagai sektor perekonomian. Terserapnya penduduk di berbagai sektor perekonomian disebabkan oleh adanya permintaan akan tenaga kerja. Oleh karena itu, faktor-faktor yang mempengaruhi permintaan tenaga kerja juga akan mempengaruhi penyerapan tenaga kerja.

\section{Pertumbuhan Ekonomi}

Pertumbuhan ekonomi (Economic growth) tercapai bila terdapat peningkatan perbandingan antara input dan output yang lebih besar serta adanya perkembangan ekonomi. Jadi adanya kenaikan output persatuan input atau setiap kesatuan input dapat menghasilkan output yang lebih besar. Ini artinya ada peningkatan efisiensi dan peningkatan produktivitas. 
Menurut Wijaya (2000) pertumbuhan ekonomi adalah proses dimana terjadi kenaikan produk nasional bruto riel atau pendapatan nasional riel. Jadi perekonomian dikatakan tumbuh atau berkembang bila terjadi pertumbuhan output riel. Disisi lain Gill (2003) mengartikan pertumbuhan ekonomi sebagai naiknya pendapatan perkapita dari sebuah perekonomian dari tahun sebelumnya.

Hal pokok dari pertumbuhan ekonomi adalah naiknya pendapatan perkapita dari sebuah perekonomian. Oleh karena itu kebijakan yang lebih berorientasi kepada pertumbuhan kurang memperhatikan aspek pemerataan pembangunan. Namun demikian bukan berarti aspek pertumbuhan tidak penting dalam kajian perencanaan pembangunan suatu daerah.

Untuk mengukur laju pertumbuhan ekonomi digunakan indikator perkembangan PDRB dari tahun ketahun. Pertumbuhan ekonomi dapat diartikan sebagai kenaikan PDRB, tanpa memandang apakah kenaikan itu lebih besar atau lebih kecil dari pertumbuhan penduduk atau apakah perubahan struktur ekonomi berlaku atau tidak (Sukirno, 2001). Kuznets dalam Todaro (2003) mengemukan bahwa pertumbuhan ekonomi merupakan masalah jangka panjang untuk mensupply berbagai benda ekonomi kepada masyarakatnya. Produk Domestik Regional Bruto (PDRB) merupakan jumlah seluruh nilai tambah yang dihasilkan oleh berbagai lapangan usaha atau sektor, yang melakukan kegiatan usahanya disuatu region atau wilayah tanpa memperhatikan faktor-faktor produksi yang dipakai.

Indikator untuk mengukur keberhasilan pembangunan suatu daerah yang dilihat dari laju pertumbuhan daerah tersebut, antara lain :

1. Mengukur laju pertumbuhan ekonomi wilayah tersebut secara sektoral sehingga dapat dimonitor sektor-sektor apa saja yang menyebabkan tinggi rendahnya pertumbuhan wilayah tersebut.

2. Mengetahui struktur perekonomian suatu wilayah yang tercermin dari peranan masing-masing sektor dalam pembentukan PDRB wilayah tersebut di samping itu dapat dilihat ada tidaknya pergeseran struktur ekonomi dari satu sektor ke sektor lain.

3. Dapat digunakan sebagai alat mengukur elastisitas penyerapan tenaga kerja setiap sektor. 


\section{Konsep Investasi}

Investasi dapat diartikan sebagai pengeluaran atau perbelanjaan penanam-penanam modal atau perusahaan untuk membeli barang-barang modal dan perlengkapanperlengkapan produksi untuk menambah kemampuan memproduksi barang-barang dan jasa yang tersedia dalam perekonomian (Sukirno, 2001). Senada dengan Sukirno secara implisit (Rosyidi, 2006) mengartikan investasi adalah bagian dari output/GNP yang diwujudkan dalam bentuk penambahan alat-alat kapital atau barang-barang modal. Dengan kata lain, investasi dimaksudkan sebagai penambahan terhadap kapasitas produktif (productive capacity). Mesin-mesin, Gudang, truk, traktor dan sebagainya adalah contoh-contoh yang jelas untuk barang investasi ini. Dalam pengertian investasi disini merupakan alat untk memperluas skala produksi.

Investasi asing pada prinsipnya hanya terdapat pada negara-negara yang memiliki perekonomian yang terbuka. Hal ini sebagaimana dikemukakan Boediono (2002). Investasi merupakan mesin penggerak pertumbuhan ekonomi. Pada perekonomian tertutup, sumber dana investasi semata-mata berasal dari tabungan dalam negeri, sedangkan dalam perekonomian terbuka sumber dana dapat diperoleh melalui pinjaman luar negeri, termasuk investasi asing.

Investasi sangat diperlukan dalam kegiatan pembangunan. Sebagaimana diungkapkan oleh Todaro (2001) mengemukakan bahwa investasi adalah salah satu faktor yang mempengaruhi pertumbuhan ekonomi, yang pada prinsipnya memaparkan pentingnya peranan modal atau akumulasi modal dalam menggerakkan pertumbuhan ekonomi suatu negara, termasuk di dalamnya investasi baru. Dengan demikian upaya mengembangkan pembangunan perekonomian sangat di dukung oleh investasi.

Secara lebih terperinci Winardi (2003) mengartikan investasi sebagai :

1. Pembelian saham-saham, setelah dilakukan analisa akan menjamin modal yang dilekatkan memberikan hasil yang memuaskan. faktor-faktor tersebut yang membedakan investasi dan spekulasi.

2. Dalam teori ekonomi maka investasi berarti pemberian alat-alat produksi (termasuk di dalamnya benda-benda untuk dijual). 
Sementara itu Boediono (2002) mendefinisikan investasi sebagai pengeluaran oleh sektor produsen untuk pembelian barang dan jasa untuk menambah stok di gudang atau pabrik. Dimana pembelian barang dan jasa tersebut diharapkan akan meningkatkan produksi. Dengan demikian yang dimaksud dengan investasi adalah pengeluaran yang dilakukan untuk menambah barang-barang modal yang digunakan untuk melakukan produksi.

Mangkusoebroto (2002) membedakan investasi ke dalam dua kategori, yaitu investasi riil dan investasi finansial. Yang dimaksud dengan investasi riil adalah investasi terhadap barang-barang yang tahan lama (barang-barang modal) yang akan digunakan dalam proses produksi. Jenis-jenis investasi ini dibedakan lagi menjadi tiga komponen, yaitu investasi tetap perusahaan (Busines fixed Investment), investasi untuk perumahan (residential constraction) dan investasi perubahan bersih persediaan perusahaan (net change business inventory). Sedangkan investasi finansial adalah merupakan investasi terhadap surat-surat berharga misalnya pembelian saham, obligasi dan lain sebagainya.

\section{Upah Minimum}

Upah Minimum adalah suatu standar minimum yang digunakan oleh para pengusaha atau pelaku industri untuk memberikan upah kepada pekerja di dalam lingkungan usaha atau kerjanya (UU No. 13 Tahun 2003). Karena pemenuhan kebutuhan yang layak di setiap provinsi berbeda-beda, maka disebut Upah Minimum Provinsi. Upah Minimum adalah suatu penerimaan bulanan minimum (terendah) sebagai imbalan dari pengusaha kepada karyawan untuk suatu pekerjaan atau jasa yang telah atau akan dilakukan dan dinyatakan atau dinilai dalam bentuk uang yang ditetapkan atas dasar suatu persetujuan atau peraturan perundang-undangan serta dibayarkan atas dasar suatu perjanjian kerja antara pengusaha dengan karyawan termasuk tunjangan, baik karyawan itu sendiri maupun untuk keluarganya. Sebagaimana yang telah diatur dalam PP No. 8/1981 upah minimum dapat ditetapkan secara minimum regional, sektoral regional maupun subsektoral, meskipun saat ini baru upah minimum regional yang dimiliki oleh setiap daerah.

Berdasarkan Undang Undang No 13 tahun 2003 disebutkan bahwa upah minimum hanya ditujukan bagi pekerja dengan masa kerja 0 (nol) sampai dengan 1 (satu) tahun. Definisi tersebut terdapat dua unsur penting dari upah minimum (Sumarsono, 2003) yaitu adalah: 
1. Upah permulaan adalah upah terendah yang harus diterima oleh buruh pada waktu pertama kali dia diterima bekerja.

2. Jumlah upah minimum haruslah dapat memenuhi kebutuhan hidup buruh secara minimal yaitu kebutuhan untuk sandang, pangan dan keperluan rumah tangga.

Upah minimum diperlukan untuk memenuhi kebutuhan pekerja agar sampai pada tingkat pendapatan "living wage", yang berarti bahwa orang yang bekerja akan mendapatkan pendapatan yang layak untuk hidupnya. Upah minimum dapat mencegah pekerja dari eksploitasi tenaga kerja terutama yang low skilled. Upah minimum dapat meningkatkan produktifitas tenaga kerja dan mengurangi konsekuensi pengangguran seperti yang diperkirakan teori ekonomi konverisional (Sukirno, 2005).

\section{METODE PENELITIAN}

Metode yang digunakan dalam penulisan ini adalah riset kepustakaan (library research). Riset kepustakaan ini dilakukan dengan mempelajari teori-teori dan informasi yang berasal dari kepustakaan, laporan-laporan, artikel-artikel yang berhubungan dengan penelitian ini untuk memperoleh landasan teori dan informasi yang diinginkan dalam penelitian ini.

Pada penelitian ini, data yang digunakan adalah data time series dari tahun 2007 sampai tahun 2018. Data yang digunakan adalah data sekunder yang terdiri dari pertumbuhan ekonomi Kota Jambi, upah, investasi daerah dan tenaga kerja di Kota Jambi tahun 2007-2018 yang diperoleh dari beberapa sumber antara lain dari BPS Kota Jambi maupun BPS Provinsi Jambi serta instansi terkait lainnya dalam pencarian dan kelengkapan data yang dibutuhkan.

Untuk mengetahui kondisi perkembangan variabel penelitian maka digunakanlah rumus sebagai berikut:

Dimana:

$$
G=\frac{P t-P t-{ }_{1}}{P t-1} \times 100 \%
$$

$\mathrm{G} \quad=$ Laju perkembangan variabel $\mathrm{X}$

$\mathrm{Pt} \quad=$ Data tahun ke $\mathrm{n}$ variabel Tahun tertentu

$\mathrm{Pt}_{-1} \quad=$ Data tahun sebelumnya variabel Tahun Sebelumnya

Alat analisis yang digunakan adalah regresi linear berganda dengan menggunakan aplikasi SPSS seri 22. Regresi berkenaan dengan studi ketergantungan dari satu peubah yang disebut peubah tidak bebas. pada satu atau lebih peubah bebas yaitu peubah yang menerangkan, dengan tujuan untuk memperkirakan dan atau meramalkan nilai rata-rata dari peubah tidak bebas apabila nilai peubah bebas sudah diketahui (Gujarati, 2006). 
Hubungan di antara peubah ini dapat dimodelkan dalam suatu persamaan matematik yang disebut persamaan regresi. Apabila dalam persamaan regresi terdapat lebih dari dua peubah dalam hubungan yang berbentuk linier maka disebut regresi linier berganda (multiple linear regression) yang dapat tuliskan dalam bentuk persamaan sebagai berikut: Model regresi yang digunakan adalah model regresi linear berganda dengan menggunakan logaritma dapat dirumuskan:

Keterangan :

$$
Y=\beta_{0}+\beta_{1} X_{1}+\beta_{2} X_{2}+\beta_{3} X_{3}+e
$$

$\mathrm{Y}=$ Tenaga Kerja (jiwa),

$\mathrm{X}_{1} \quad=$ Pertumbuhan Ekonomi (persen)

$\mathrm{X}_{2}$ = Investasi (rupiah),

$\mathrm{X}_{3}=$ Upah Minimum Provinsi (rupiah),

$\beta_{1-3}=$ Koefisien regresi untuk regresi variabel $\mathrm{x}$

\section{PEMBAHASAN}

Analisis Deskriptif Penyerapan Tenaga Kerja di Kota Jambi

Untuk lebih jelasnya penyerapan tenaga kerja di Kota Jambi dapat dilihat pada tabel 1 .

Tabel 1. Penyerapan Tenaga Kerja Di Kota Jambi

\begin{tabular}{|l|l|l|}
\hline Tahun & $\begin{array}{l}\text { Tenaga Kerja (Bekerja) } \\
\text { (Jiwa) }\end{array}$ & $\begin{array}{l}\text { Perkembangan } \\
\text { (Persen) }\end{array}$ \\
\hline 2007 & 176.688 & - \\
\hline 2008 & 191.661 & 8,47 \\
\hline 2009 & 195.868 & 2,20 \\
\hline 2010 & 218.401 & 11,50 \\
\hline 2011 & 238.307 & 9,11 \\
\hline 2012 & 226.607 & $-4,91$ \\
\hline 2013 & 230.243 & 1,60 \\
\hline 2014 & 235.722 & 2,38 \\
\hline 2015 & 254.351 & 7,90 \\
\hline 2016 & 266.509 & 4,78 \\
\hline 2017 & 268.264 & 0,66 \\
\hline 2018 & 277.802 & 3,56 \\
\hline Rata-Rata & $\mathbf{4 , 3 0}$ \\
\hline
\end{tabular}

Sumber : Data BPS Kota Jambi 
Berdasarkan tabel 1 tergambar bahwa jumlah penduduk bekerja yang ada di Kota Jambi dari tahun ke tahun menunjukkan kecenderungan yang terus meningkat. Peningkatan ini disebabkan karena semakin berkembangnya sektor ekonomi maupun disebabkan terbukanya peluang usaha bagi masyarakat. Selama tahun 2007-2018 jumlah penduduk yang bekerja di Kota Jambi secara rata-rata mengalami peningkatan sebesar 4,30 persen per tahun.

Pertumbuhan penduduk bekerja tertinggi di Kota Jambi selama periode 2007-2018 terjadi pada tahun 2010 yaitu sebesar 11,50 persen. Tingginya laju pertumbuhan ini disebabkan oleh banyaknya migran yang masuk ke Kota Jambi untuk mencari pekerjaan sebagai akibat dari adanya CPNS dan perkembangan daerah dan peluang usaha yang masih terbuka luas, sedangkan pertumbuhan penduduk yang bekerja terendah terjadi pada tahun 2012 yaitu sebesar -4,91 persen. Rendahnya disebabkan kondisi ekonomi Kota Jambi yang terdampak krisis akibat dari tingginya inflasi dan rendahnya daya beli masyarakat. Sehingga menyebabkan kesulitan dalam mencari dan membuka lapangan kerja pada saat itu.

\section{Analisis Kuantitatif Faktor Yang Mempengaruhi Penyerapan Tenaga Kerja di Kota Jambi}

Analisis perumusan masalah yang kedua digunakan dalam pengujian model kuantitatif dalam penelitian ini adalah dengan menggunakan Metode Linier Berganda, dengan menggunakan teknik Ordinary Least Square dengan menggunakan program SPSS , dimana hasil Hipotesis pengujian model Regresi Linier Berganda dapat dilihat sebagai berikut:

$$
\mathbf{Y}=\boldsymbol{\beta}_{0}+\boldsymbol{\beta}_{1} \mathbf{X}_{1}+\boldsymbol{\beta}_{2} \mathbf{X}_{2}+\boldsymbol{\beta}_{3} \mathbf{X}_{3}+\mathbf{e}
$$

Keterangan :

$\mathrm{Y}=$ Tenaga Kerja (jiwa),

$\mathrm{X}_{1} \quad=$ Pertumbuhan Ekonomi (persen)

$\mathrm{X}_{2}=$ Investasi (rupiah),

$\mathrm{X}_{3}=$ Upah Minimum Provinsi (rupiah),

$\beta_{1-3}=$ Koefisien regresi untuk regresi variabel $\mathrm{x}$ 


\begin{tabular}{|c|c|c|c|c|c|c|}
\hline \multicolumn{7}{|c|}{$\begin{array}{c}\text { Tabel. } 2 \text { : Hasil SPSS Model Regresi Linear Berganda } \\
\text { Coefficients }^{\mathbf{a}^{\mathrm{a}}}\end{array}$} \\
\hline \multirow{2}{*}{\multicolumn{2}{|c|}{ Model }} & \multicolumn{2}{|c|}{ Unstandardized Coefficients } & \multirow{2}{*}{$\begin{array}{c}\text { Standardized } \\
\text { Coefficients }\end{array}$} & \multirow[b]{2}{*}{$\mathrm{t}$} & \multirow[b]{2}{*}{ Sig. } \\
\hline & & $\mathrm{B}$ & Std. Error & & & \\
\hline 1 & (Constant) & 3,489 & ,415 & & 8,406 & ,000 \\
\hline & $\mathrm{X} 1$ & 630 & 156 & 1,318 & 4,038 & 000 \\
\hline & $\mathrm{X} 2$ & ,087 &, 025 & 349 & 3,480 & ,004 \\
\hline & X3 & 291 & 091 &, 860 & 3,212 & 012 \\
\hline
\end{tabular}

a. Dependent Variable: Y

Makna interpretasi dari tabel 5.2 dapat dituliskan dalam persamaan sebagai berikut:

$$
Y=3,489+0,630 X_{1}+0,087 X_{2}+0,291 X_{3}+e
$$

Dari hasil persamaan regresi diatas maka dapat diartikan dan dibahas sebagai berikut:

1. Secara keseluruhan bahwa nilai koefisien $\beta_{0}$ (Constant) sebesar 3,489 artinya, apabila selama tahun 2007 sampai 2018 tidak terjadi perubahan variabel pertumbuhan ekonomi $\left(\mathrm{X}_{1}\right)$, investasi $\left(\mathrm{X}_{2}\right)$ dan UMP $\left(\mathrm{X}_{3}\right)$ di Kota Jambi tidak mengalami perubahan atau dengan asumsi konstan, maka penyerapan tenaga kerja (Y) untuk Provinsi Jambi sebesar 3,489 persen.

2. Sedangkan koefisien regresi variabel pertumbuhan ekonomi $\left(\mathrm{X}_{1}\right) \quad\left(\beta_{1}\right)$ diperoleh nilai sebesar 0,630 artinya apabila terjadi kenaikan atau peningkatan pertumbuhan ekonomi sebesar 1 persen, maka akan meningkatkan penyerapan tenaga kerja untuk Kota Jambi sebesar 0,630 persen dengan asumsi bahwa variabel lain tetap (Cateris paribus) atau tidak terjadi perubahan atau konstan. Hasil regresi untuk koefisien pertumbuhan ekonomi $\left(\mathrm{X}_{1}\right)$ bernilai positif, karena dengan meningkatnya laju pertumbuhan ekonomi tentu akan diikuti peningkatan jumlah tenaga kerja dan angkatan kerja. Karena terjadi peningkatan output barang dan jasa yang akan meningkatkan laju pertumbuhan lapangan kerja. Pertumbuhan ekonomi semakin tinggi Kota Jambi memberikan pengaruh positif atau menaikkan penyerapan tenaga kerja. 
3. Koefisien regresi variabel investasi $\left(\beta_{2}\right)$ diperoleh nilai sebesar 0,087 memiliki makna apabila terjadi kenaikan atau peningkatan investasi $\left(\mathrm{X}_{2}\right)$ sebesar 1 persen, maka akan meningkatkan penyerapan tenaga kerja Kota Jambi (Y) sebesar 0,087 persen dengan asumsi bahwa variabel lain tetap (Cateris paribus) atau tidak terjadi perubahan atau konstan.

4. Koefisien regresi variabel upah minimum provinsi $\left(\beta_{3}\right)$ diperoleh nilai sebesar 0,291 memiliki makna apabila terjadi kenaikan atau peningkatan upah minimum provinsi $\left(\mathrm{X}_{3}\right)$ sebesar 1 persen, maka akan meningkatkan penyerapan tenaga kerja Kota Jambi (Y) sebesar 0,291 persen dengan asumsi bahwa variabel lain tetap (Cateris paribus) atau tidak terjadi perubahan atau konstan.

\section{Uji Hipotesis}

Uji Parsial (Uji-t)

Coefficients $^{\text {a }}$

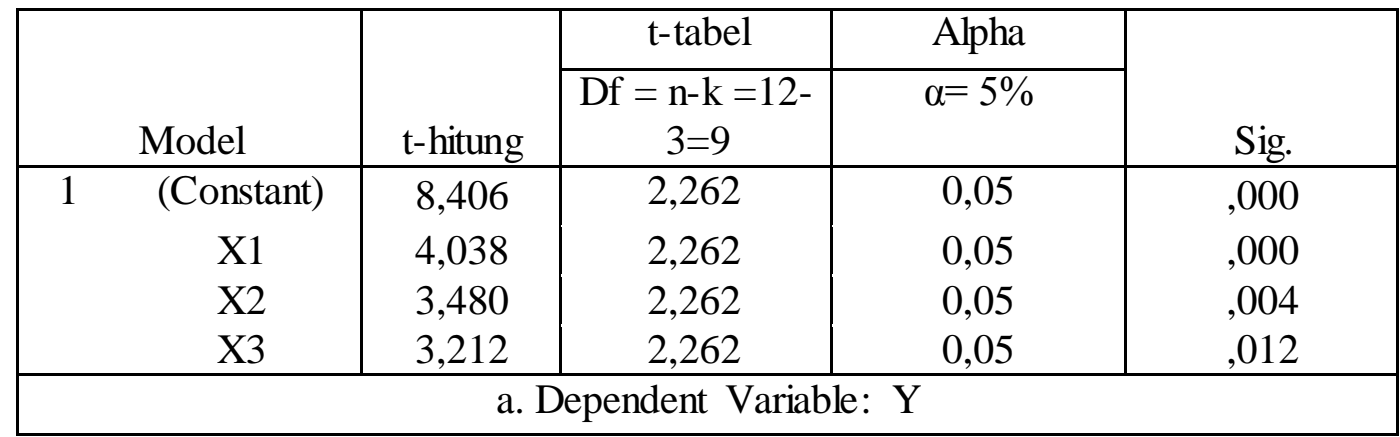

Berdasarkan uji statistik parsial dengan tingkat keyakinan $\alpha=5 \%$, diperoleh:

1. Nilai sig untuk variabel pertumbuhan ekonomi $\left(\beta_{1}\right)$ yang nilainya lebih kecil dari alpha $5 \%(0,000<0,05)$ atau dilihat dari t-hitung lebih besar dari t-tabel $(4,038>2,262)$ artinya $\mathrm{H}_{0}$ ditolak $\mathrm{H}_{1}$ diterima. Dapat terlihat pertumbuhan ekonomi $\left(\mathrm{X}_{1}\right)$ selama periode 2007 sampai dengan 2018 berpengaruh positif dan signifikan terhadap peningkatan penyerapan tenaga kerja di Kota Jambi dengan tingkat keyakinan $\alpha$ dibawah 5 persen. Dengan demikian hipótesis yang menyatakan pertumbuhan ekonomi berpengaruh positif dan signifikan terhadap penyerapan tenaga kerja Kota Jambi dapat diterima 
2. Nilai sig untuk variabel investasi $\left(\beta_{2}\right)$ yang nilainya lebih kecil dari alpha $5 \%(0,004<0,05)$ atau dilihat dari t-hitung lebih besar dari t-tabel $(3,480>2,262)$ artinya $\mathrm{H}_{0}$ ditolak $\mathrm{H}_{1}$ diterima. Dapat terlihat investasi $\left(\mathrm{X}_{2}\right)$ selama periode 2007 sampai dengan 2018 berpengaruh positif dan signifikan terhadap peningkatan penyerapan tenaga kerja di Kota Jambi dengan tingkat keyakinan $\alpha$ dibawah 5 persen. Dengan demikian hipótesis yang menyatakan investasi berpengaruh positif dan signifikan terhadap penyerapan tenaga kerja Kota Jambi dapat diterima

3. Nilai Sig untuk variabel UMP $\left(\beta_{3}\right)$ diperoleh nilai yang lebih kecil dari alpha $5 \%(0,012<0,05)$ atau dilihat dari t-hitung lebih besar dari t-tabel $(3,212>2,262)$ artinya $\mathrm{H}_{0}$ ditolak $\mathrm{H}_{1}$ diterima. Dapat terlihat UMP $\left(\mathrm{X}_{3}\right)$ selama periode 2007 sampai dengan 2018 berpengaruh positif dan signifikan terhadap peningkatan penyerapan tenaga kerja di Kota Jambi dengan tingkat keyakinan a dibawah 5 persen. Dengan demikian hipótesis yang menyatakan UMP berpengaruh positif dan signifikan terhadap penyerapan tenaga kerja Kota Jambi dapat diterima.

\section{Uji Simultan (Uji-F)}

ANOVA $^{\mathrm{a}}$

\begin{tabular}{|cc|c|c|c|c|c|c|}
\hline & Model & Sum of Squares & df & $\begin{array}{c}\text { Mean } \\
\text { Square }\end{array}$ & F-hitung & Sig. & $\begin{array}{c}\text { F- } \\
\text { tabel }\end{array}$ \\
\hline 1 & $\begin{array}{c}\text { Regression } \\
\text { Residual } \\
\text { Total }\end{array}$ &, 039 & 3 &, 013 & 32,443 &, $000^{\mathrm{b}}$ & 4,459 \\
& & 8 &, 000 & & & \\
\hline
\end{tabular}

a. Dependent Variable: Y

b. Predictors: (Constant), X3, X1, X2

Berdasarkan persamaan diatas, diperoleh nilai F-hitung lebih besar dari nilai F-tabel $(32,443>4,459)$ pada tingkat keyakinan $\alpha=5 \%$ atau sig lebih kecil dari alpha $(0,000<0,05)$. Artinya, $\mathrm{H}_{0}$ ditolak dan $\mathrm{H}_{1}$ diterima. Secara bersama-sama variabel pertumbuhan ekonomi $\left(\mathrm{X}_{1}\right)$, investasi $\left(\mathrm{X}_{2}\right)$ dan UMP $\left(\mathrm{X}_{3}\right)$ berpengaruh signifikan terhadap naik turunnya kesempatan kerja (Y) Kota Jambi selama periode 2007 sampai dengan 2018. 


Tingkat Signifikansi R-Squared $\left(\mathbf{R}^{2}\right)$
Model Summary
\begin{tabular}{|l|l|l|l|l|}
\hline Model & R & R Square & $\begin{array}{l}\text { Adjusted } \\
\text { Square }\end{array}$ & $\begin{array}{l}\text { R Std. Error of the } \\
\text { Estimate }\end{array}$ \\
\hline 1 &, $961^{\text {a }}$ &, 924 &, 896 &, 02005 \\
\hline
\end{tabular}

a. Predictors: (Constant), X3, X1, X2

b. Dependent Variable: Y

Dari hasil perhitungan R-squared yang ditunjukkan pada persamaan diatas diperoleh nilai R-squared $\left(\mathrm{R}^{2}\right)$ sebesar 0,924. Artinya sekitar 92,40 persen naik turunnya kesempatan kerja (Y) Kota Jambi tahun 2007-2018 dipengaruhi oleh variabel pertumbuhan ekonomi $\left(\mathrm{X}_{1}\right)$, investasi $\left(\mathrm{X}_{2}\right)$ dan UMP $\left(\mathrm{X}_{3}\right)$. Sedangkan sisanya 7,60 persen, dijelaskan oleh variabel lain yang tidak dimasukan kedalam persamaan regresi. Jika dilihat dari nilai $\mathrm{R}$ sebesar 0,961 atau 96,10 persen. Artinya hubungan ketiga variabel bebas yaitu pertumbuhan ekonomi $\left(\mathrm{X}_{1}\right)$, investasi $\left(\mathrm{X}_{2}\right)$ dan UMP $\left(\mathrm{X}_{3}\right)$ terhadap variabel terikat yaitu kesempatan kerja (Y) Kota Jambi selama tahun 20072018 secara bersama-sama sangat kuat.

\section{PEMBAHASAN}

Hasil yang diperoleh untuk meningkatkan penyerapan tenaga kerja yaitu perlu upaya pemerintah untuk memacu pertumbuhan ekonomi pada setiap sektor. Hal ini tentu saja diharapkan akan semakin membuka peluang kesempatan kerja dan berusaha yang lebih besar pada masyarakat. Penciptaan kesempatan kerja merupakan salah satu sasaran pembangunan ekonomi dan sekaligus menjadi instrumen utama dalam pemerataan hasil-hasil pembangunan. Secara makro ekonomi, perkembangan kesempatan kerja nasional dipengaruhi oleh pertumbuhan ekonomi nasional. Dengan demikian dapat dikatakan bahwa jumlah kesempatan kerja yang tersedia dalam kurun waktu tertentu merupakan cerminan dari daya dukung ekonomi dalam penggunaan sumberdaya manusia yang tersedia.

Peningkatan kegiatan ekonomi daerah di berbagai sektor akan memberikan dampak, baik langsung maupun tidak langsung terhadap penciptaan lapangan kerja. Tanggung jawab ideal dari dunia kerja adalah bagaimana dapat menyerap sebesar-besarnya tambahan angkatan kerja baru (new labor force) yang terjadi setiap tahun, dengan tetap memperhatikan aspek peningkatan produktivitas tenaga kerja. Peningkatan produktivitas berkorelasi positif dengan pendapatan yang pada gilirannya akan mendorong peningkatan kesejahteraan para tenaga kerja dan keluarganya. 
Untuk Investasi berdasarkan hasil penelitian menunjukkan bahwa satu hal yang pasti dari naiknya investasi maka akan meningkatnya modal dan produksi barang atau jasa yang akan mendorong terciptanya lapangan kerja baru untuk memenuhi permintaan atas tenaga kerja yang ada di Kota Jambi tentu penyerapan tenaga kerja juga akan meningkat. Namun yang menarik dalam penelitian ini yaitu pengaruh investasi terhadap peningkatan penyerapan tenaga kerja masih kecil dibandingkan pertumbuhan ekonomi dan upah minimum provinsi

Dengan meningkatnya penghasilan maka akan terpenuhinya standar kebutuhan hidup layak. Namun akan menjadi beban perusahaan jika kenaikan UMP tidak dibarengi dengan peningkatan Produktivitas sumber daya manusia. Namun untuk Kota Jambi dengan adanya kenaikan UMP tentu dapat meningkatnya penyerapan tenaga kerja karena UMP berpengaruh positif dalam penelitian ini

\section{KESIMPULAN DAN SARAN}

Berdasarkan hasil penelitian dan pembahasan maka dapat disimpulkan beberapa hal sebagai berikut:

1. Perkembangan penyerapan tenaga kerja di Kota Jambi juga mengalami peningkatan berfluktuasi selama periode 2007-2018.

2. Secara parsial berdasarkan uji $t$ dan uji $F$ variabel bebas pertumbuhan ekonomi $\left(\mathrm{X}_{1}\right)$, investasi $\left(\mathrm{X}_{2}\right)$ dan upah minimum provinsi $\left(\mathrm{X}_{3}\right)$ berpengaruh positif dan signifikan terhadap penyerapan tenaga kerja (Y) Kota Jambi selama periode 2007-2018.

Dapat penulis kemukakan beberapa saran sebagai berikut :

1. Dalam penelitian ini ditemukan pertumbuhan meningkat diikuti meningkatnya penyerapan tenaga kerja, namun investasi dan upah minimum provinsi masih relatif rendah dalam meningkatkan penyerapan tenaga kerja Kota Jambi. Maka dari itu hendaknya pemerintah perlu melakukan perbaikan kualitas sumber daya manusia agar penyerapan tenaga kerja tetap tinggi meskipun upah minimum provinsi meningkat yang dibarengi peningkatan investasi dan pertumbuhan ekonomi, sehingga kesejahteraan masyarakat di Kota Jambi dapat terpenuhi.

2. Pemerintah diharapkan menciptakan lapangan kerja baru yang dibutuhkan agar semua lapisan masyarakat dapat terserap dalam pasar kerja serta lebih mengembangkan sektor usaha yang dapat menyerap banyak tenaga kerja di Kota Jambi melalui alokasi investasi yang produktif meningkatkan pertumbuhan ekonomi daerah. 


\section{DAFTAR PUSTAKA}

Anonim (2019) PDRB Kota Jambi Menurut Lapangan Usaha Tahun 20102018. Kerjasama Bappeda dan BPS Kota Jambi, Jambi.

-(2019). PDRB Provinsi Jambi Menurut Lapangan Usaha Tahun 2010-2018. Kerjasama Bappeda dan BPS Provinsi Jambi, Jambi.

- (2019) Kota Jambi Dalam Angka 2015. Kerja Sama Bappeda dan BPS Kota Jambi, Jambi.

Arsyad, Lincolin, 2001, "Pengantar Perencanaan dan Pembangunan Ekonomi Daerah”, Edisi Pertama, Penerbit BPFE, Yogyakarta.

Arsyad, Lincolin 2009. Pengantar Perencanaan dan Pembangunan Ekonomi Daerah. BP-FE, Yogyakarta.

Djojohadikusumo, Soemitro, 2006, Ekonomi Pembangunan, LP FE-UI, Jakarta

Boediono, 2001. Teori Pertumbuhan Ekonomi, Yogyakarta : BPFE, Yogyakarta.

Boediono. 2002. Seri Sinopsis, Pengantar Ilmu Ekonomi, Ekonomi Mikro, BPFE, Yogyakarta.

Dumairy. 2002. Perekonomian Indonesia. Jakarta : Erlangga.

Febryana Rizqi Wasilaputri. 2016. Pengaruh Upah Minimum Provinsi,

PDRB dan Investasi Terhadap Penyerapan Tenaga Kerja Di Pulau Jawa

Tahun 2010-2014. Jurnal Ilmiah . Universitas Negeri Yogyakarta.

Ghozali, Imam, Arifin Sabeni. 2006. Pokok-pokok Akuntansi Pemerintahan.

Edisi 4. Penerbit BPFE: Yogyakarta.

Gill O. James dan Chatton Moira, 2003, Penerjemah : Dwi Prabaningtyas, Memahami Laporan Keuangan, PPM, Jakarta

Jhingan, ML. 2002. Ekonomi Pembangunan dan Perencanaan. Jakarta. PT. Raja Grafindo Persada. 
Kuncoro, Mudrajad, 2000, Ekonomi Pembangunan, UPP YKPN, Yogyakarta

Mangkoesoebroto G.2002. Ekonomi Publik. BPFE, Yogyakarta.

Setiawan, 2010. Analisis Penyerapan Tenaga Kerja Pada Sektor Usaha Kecil dan Menengah di Kota Semarang. Jurnal Ilmiah Ekonomi Dipublikasikan.

Simanjuntak, Payaman J. 2011. Manajemen \& Evaluasi Kinerja. Jakarta: Fakultas Ekonomi Universitas Indonesia

Sukirno, Sadono, 2001, Makro ekonomi, PT Raja Grafindo Persada, Jakarta.

Sukirno, Sadono (2008). Pengantar Teori Makro Ekonomi. Jakarta. PT. Raja Grafindo Persada.

Suparmoko, 2001, Ekonomika Pembangunan, BP FE-UGM, Yogyakarta.

Todaro,MP. 2003. Ekonomi di Dunia Ketiga, Ghalia Indonesia, Jakarta.

Todaro, Michael P. (2006). Pembangunan Ekonomi di Dunia Ketiga (Terjemahan Oleh Drs. Haris Munandar, M.A). Erlangga, Jakarta.

Utami, Ratri Heningtyas .2013. Pengaruh Tenaga Kerja, Upah Minimum Regional (UMR), Pendapatan Asli Daerah (PAD) terhadap PDRB Perkapita Kabupaten/Kota Di Kawasan KEDUNGSEPUR (Kendal, Demak, Ungaran, Semarang, Grobogan dan Salatiga). Jurnal Ilmiah. Universitas Negeri Semarang.

Wijaya, Bayu dan Atmanti, Hastarini Dwi, 2000. Analisis pengembangan wilayah dan sektor potensial guna mendorong pembangunan di Kota Salatiga. Dinamika Pembangunan Vol.3 No.2, Desember 2000. https://ojs.unud.ac.id/index.php/EEB/article/view/22862/16240 eprints.ums.ac.id/32022/9/Naskah\%20Publikasi.pdf 